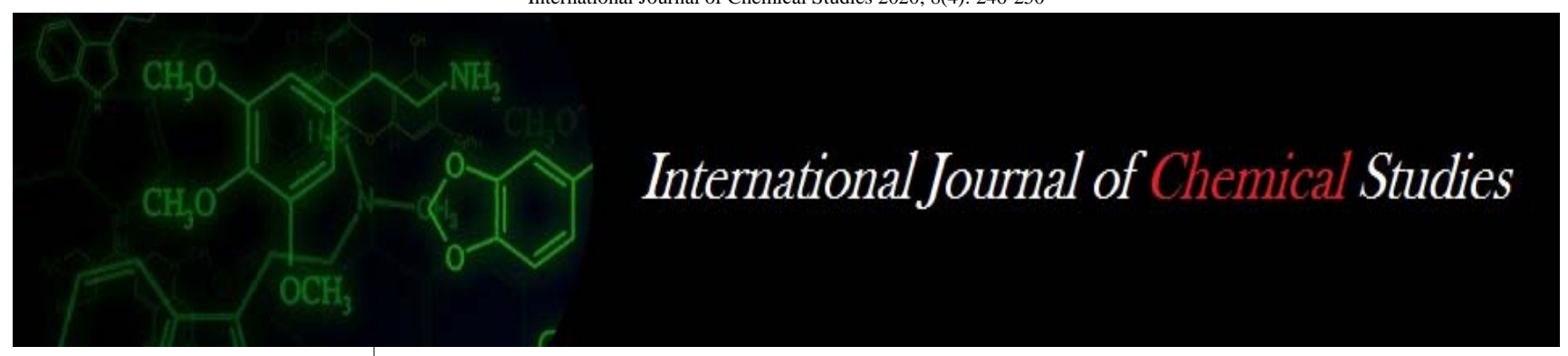

P-ISSN: 2349-8528 E-ISSN: 2321-4902 www.chemijournal.com IJCS 2020; 8(4): 246-250 (C) 2020 IJCS

Received: 18-05-2020 Accepted: 21-06-2020

Debashis Bindhani MSc Scholar, Department of Agronomy, Bidhan Chandra Krishi Vishwavidyalay, Haringhata, West Bengal, India

Subhendu Bikash Goswami Professor, Department of Agronomy, Bidhan Chandra Krishi Vishwavidyalay, Haringhata, West Bengal, India

Somanath Nayak PhD Scholar, Division of Agronomy, Indian Agricultural Research Institute, New Delhi, India
Corresponding Author: Somanath Nayak PhD Scholar, Division of Agronomy, Indian Agricultural Research Institute, New Delhi, India

\section{Growth and yield of hybrid mustard as influenced by irrigation scheduling and nitrogen management}

\author{
Debashis Bindhani, Subhendu Bikash Goswami and Somanath Nayak
}

DOI: https://doi.org/10.22271/chemi.2020.v8.i4d.9699

\begin{abstract}
The field experiment entitled "Growth and yield of hybrid mustard as influenced by irrigation scheduling and nitrogen management" was conducted at the Central Research Farm, Bidhan Chandra Krishi Viswavidyalaya, Mohanpur, West Bengal during rabi season (2017-18) in alluvial soil having medium soil fertility. It was conducted in split-plot design with three replications comprising 3-main plot irrigation scheduling treatments based in IW/CPE $=0.8,1.0 \& 1.2$; and three sub-plot treatments of nitrogen @ 40, 80 \& $120 \mathrm{~kg} / \mathrm{ha}$. The result of experiment revealed that the growth and yield of hybrid mustard crop was significantly influenced by both the main and sub-plot treatments. The maximum growth parameter like plant height, dry matter accumulation, CGR of hybrid mustard crop were recorded with IW/CPE=1.2 irrigation level and $120 \mathrm{~kg} \mathrm{~N} / \mathrm{ha}$. The yield attributes and yield also followed the similar trend, maximum yield was obtaied with application of $120 \mathrm{~kg} \mathrm{~N} / \mathrm{h}$ under irrigation regime scheduled at IW/CPE $=1.2$. The yield variation due to irrigation regimes and nitrogen management was to the tune of 13.35 to $17.14 \%$ and 44.19 to $83.09 \%$, respectively.
\end{abstract}

Keywords: Irrigation scheduling, nitrogen management, hybrid mustard, growth, yield

\section{Introduction}

Rapeseed mustard, have a significant role in Indian agriculture since almost each part of the plant is consumed either by human beings or animals depending upon the crop and its growth stage. Rapeseed-mustard crops in India include toria (Brassica campestris L. var. toria), brown sarson (B. campestris L. brown sarson), yellow sarson (B. campestris L. var. yellow sarson), Indian mustard (B. juncea L. Czernj and cosson), black mustard (B. nigra) and taramira (Eruca sativa/vesicara Mill.) species. Among them, Indian mustard is an important oilseed crop of the Indian subcontinent and contributes more than $80 \%$ of the total rapeseedmustard production of the country. The oil content of Indian mustard varies between 30 to 45.7\%. It is cultivated in an area of 5.96 million hectares with a production of 8.32 million tonnes yielding $1397 \mathrm{~kg} / \mathrm{ha}$ (DOAC, 2018) ${ }^{[4]}$. In India, mustard is mainly grown in North West parts of India, Rajasthan and Uttar Pradesh are the major producing states in the country. In India, 85-90\% of total rainfall is received during rainy season (July-September) and Indian mustard is grown during winter season (October-March) on conserved moisture (Ghosh et al. 2002) ${ }^{[6]}$. The major constraint attributing to low production of mustard are scarce and untimely water supply and poor fertility status of soil. Application of irrigation at regular interval with proper nutrient management is the other two most critical inputs which can substantially increase yield of mustard (Piri et al. 2011) ${ }^{[11]}$. But the irrigated mustard is generally confined to areas with limited amounts of irrigation water, which necessitates that efficient use of water should be achieved by following the best possible irrigation schedule. Yadav et al. (2010) ${ }^{[16]}$ observed that water supply at the most critical growth stages (at flower initiation stage and siliquae development stage) achieved the maximum growth and yield attributes. However, better scientific irrigation scheduling like IW/CPE (irrigation water/ cummulative open pan evaporation) could be practiced to manage water efficiently. Nitrogen $(\mathrm{N})$ is the most important nutrient, and being a protein, it is involved in several metabolic processes that strongly influence growth, productivity and quality of crops. Yield increases in Indian mustard at various locations in India have been reported with application of $\mathrm{N}$ as high as $150 \mathrm{~kg} / \mathrm{ha}$ or more (Rathore et al. 2014) ${ }^{[14]}$. But the nitrogen use efficiency is very low (30-40\%) as it is lost $\sim 246 \sim$ 
from soil through volatilization, leaching and runoff. Hence the problem of low NUE further stress on better nitrogen management along with irrigation management. There is not much information on the effects of irrigation scheduling and nitrogen management and their interaction on growth and yield of mustard crop. Considering this, an attempt has been made here to gain a better understanding of the relationship between crop performance and water management and nitrogen metabolism. With this objective an experiment titled "Growth and yield of hybrid mustard as influenced by irrigation scheduling and nitrogen management” was planned.

\section{Material and Methods}

The field experiment was conducted at the Central Research Farm (22 ${ }^{\circ} 56^{\prime} \mathrm{N}$ latitude and 88 ${ }^{\circ} 32^{\prime} \mathrm{E}$ longitude and 9.75 meter above MSL), Gayespur, Nadia, under Bidhan Chandra Krishi Viswavidyalaya, Mohanpur, West Bengal during rabi season (2017-18) in alluvial soil having medium soil fertility (228 kg/ha total $\mathrm{N}, 30 \mathrm{~kg} / \mathrm{ha}$ available $\mathrm{P}_{2} \mathrm{O}_{5}, 198 \mathrm{~kg} / \mathrm{ha}$ available $\mathrm{K}_{2} \mathrm{O}, 0.58 \%$ Organic Carbon with $\mathrm{p}^{\mathrm{H}}$ 7.10). The experimental site is situated at the sub-tropical humid climate. The average annual rainfall is about $1500 \mathrm{~mm}$ and the mean temperature ranges from $27^{\circ} \mathrm{C}$ to $31^{\circ} \mathrm{C}$. During the experimental period the maximum monthly temperature was achieved in December $\left(32.48^{\circ} \mathrm{C}\right)$ and minimum monthly temperature was achieved in January $\left(9.97^{\circ} \mathrm{C}\right)$. The total rainfall received was $71.10 \mathrm{~mm}$ throughout the cropping period. The field experiment was conducted in Split-Plot design with three replications comprising three main plot irrigation scheduling treatments based in IW/CPE (irrigation water/cumulative open pan evaporation ratio)=0.8, $1.0 \& 1.2$; and three sub-plot treatments of Nitrogen @ 40, 80 \& 120 $\mathrm{kg} / \mathrm{ha}$. Full dose of $\mathrm{P}_{2} \mathrm{O}_{5}(40 \mathrm{~kg} / \mathrm{ha}), \mathrm{K}_{2} \mathrm{O}(40 \mathrm{~kg} / \mathrm{ha})$ and half dose of $\mathrm{N}$ (application rate as per treatment) was applied as basal doses and rest half of $\mathrm{N}$ was applied after 35 days. Sources of $\mathrm{N}, \mathrm{P}_{2} \mathrm{O}_{5}$ and $\mathrm{K}_{2} \mathrm{O}$ were Urea, SSP and MOP respectively. The experiment was conducted with a hybrid mustard variety named as PAN 70. A common irrigation was given for good germination of the seeds. Then irrigation scheduling was followed on three main plot irrigation treatments at IW/CPE $=0.8,1.0 \& 1.2$, which otherwise implies that $50 \mathrm{~mm}$ irrigation water was given at $62.5 \mathrm{~mm}$, $50.0 \mathrm{~mm}$ and $41.5 \mathrm{~mm} \mathrm{CPE}$, respectively. Data regarding plant height, number of branches per plant, dry matter accumulation was observed at harvesting stage which is mentioned in this manuscript. Then Crop growth rate for 6090 days after sowing (DAS) was determined using the formula suggested by Evans (1972) ${ }^{[5]}$. Then various yield attributes (siliqua/plant. seeds/siliqua, test weight etc) were recorded following the standard procedure at the harvesting stage. Upon harvesting sun-drying, threshing, winnowing operations of mustard crop were done and yield data were recorded. Statistical analysis and interpretation along with correlation studies of the findings were done by calculating the values of S.Em $( \pm)$ [Standard error of mean] and CD at $5 \%$ [Critical difference at $5 \%$ level of significance] as described by Gomez and Gomez (1984) ${ }^{[7]}$.

\section{Result and Discussion \\ Crop Growth Parameters}

Crop growth parameters in terms of plant height, dry matter accumulation, crop growth rates (CGR), branches/plant of hybrid mustard crop was significantly influenced by scheduling of irrigation and application of different nitrogen doses (Table 1). At harvesting highest plant $(150 \mathrm{~cm})$ height was recorded with $\mathrm{IW} / \mathrm{CPE}=1.2$ and the lowest was recorded with IW/CPE $=0.8(146 \mathrm{~cm})$. Highest dry matter accumulation $\left(873.6 \mathrm{~g} / \mathrm{m}^{2}\right)$ was recorded with $\mathrm{IW} / \mathrm{CPE}=1.2$ followed by IW/CPE $=0.8\left(771.1 \mathrm{~g} / \mathrm{m}^{2}\right)$ and the lowest was recorded with IW/CPE $=1.0\left(706.2 \mathrm{~g} / \mathrm{m}^{2}\right)$. The variation in dry matter accumulation due to irrigation regime was 13.29 to $23.70 \%$. Similarly the CGR at 60-90 DAS was recorded the highest $\left(12.9 \mathrm{~g} / \mathrm{m}^{2} /\right.$ day $)$ with $\mathrm{IW} / \mathrm{CPE}=1.2$ followed by IW/CPE $=0.8$ $\left(10.8 \mathrm{~g} / \mathrm{m}^{2} /\right.$ day $)$ and least was recorded with $\mathrm{IW} / \mathrm{CPE}=1.0(9.2$ $\mathrm{g} / \mathrm{m}^{2} /$ day). The variation in crop growth rate at $60-90$ DAS due to moisture regime was 19.44 to $40.22 \%$. The data pertaining to number of branches also followed the similar trend, highest number of branches was observed with IW/CPE=1.2 (11.2) followed by IW/CPE=1.0 (10.7) and IW/CPE $=0.8$ (9.7). The significant increase in crop growth parameter like the plant height, dry matter accumulation, CGR might be due to optimum supply of soil moisture surrounding root zone by favourably improving the nutrient uptake and translocation, higher photosynthetic activities which ultimately linked with the plant growth and development. The results are substantiated by the research findings of Piri and Sharma (2006), Dadhich et al. (2015) and Rathore et al. (2017) ${ }^{[10,1,13]}$.

Among the nitrogen management treatments in sub-plots, the application of $120 \mathrm{~kg} \mathrm{~N} / \mathrm{ha}$ recorded the highest plant height $(155 \mathrm{~cm})$ and dry matter accumulation $\left(1041.7 \mathrm{~g} / \mathrm{m}^{2}\right)$ at harvesting stage. And least plant height $(142 \mathrm{~cm})$ and dry matter accumulation (579.4 $\left.\mathrm{g} / \mathrm{m}^{2}\right)$ was observed with application of $40 \mathrm{~kg} \mathrm{~N} / \mathrm{ha}$. The variation in dry matter accumulation due to nitrogen doses was 42.74 to79.79\%. Highest CGR (15.6 g/m²/day) at 60-90 DAS was recorded with $120 \mathrm{~kg}$ N/ha followed by $80 \mathrm{~kg} \mathrm{~N} / \mathrm{ha}\left(9.4 \mathrm{~g} / \mathrm{m}^{2} /\right.$ day $)$ and least was recorded with $40 \mathrm{~kg} \mathrm{~N} / \mathrm{ha}\left(7.9 \mathrm{~g} / \mathrm{m}^{2} /\right.$ day $)$. The variation in Crop growth rate at 60-90 DAS due to nitrogen doses was 65.96 to $97.46 \%$. Again application $120 \mathrm{~kg} \mathrm{~N} / \mathrm{ha}$ resulted in highest number of branches (13.7) at harvesting stage which is followed by $80 \mathrm{~kg} \mathrm{~N} / \mathrm{ha} \mathrm{(9.7)} \mathrm{and} 40 \mathrm{~kg} \mathrm{~N} / \mathrm{ha}$ (8.2). Nitrogen supply to mustard improved the integrity of plant structure and the key physiological processes such as light interception by chlorophyll, energy for carbohydrate build-up and enhanced the hydraulic conductivity of the root cortical cells, thereby improving the growth parameters. (Dhawan, 2002; Namara et al. 2007) ${ }^{[3,9]}$.

\section{Yield Attributes}

Irrigation scheduling had marked effects on siliqua/plant, seeds/siliqua and thousand seed weight (Table 2). Application of irrigation at IW/CPE=1.2 recorded highest number of siliqua per plant (140) and seeds per siliqua (15). The variation in numbers of siliqua per plant and seeds per siliqua due to moisture regime was upto 11.90 to $19.44 \%$ and 6.38 to $15.38 \%$, respectively. Enhanced water supply had resulted in a higher number of siliqua/plant, seeds/siliqua. However, highest test weight was reported from the irrigation scheduling treatment with IW/CPE=1 (3.7 g). Due to regular water supply at interval following irrigation scheduling, the crop did not suffer from water stress at reproductive stages and perhaps it facilitate better translocation of photosynthates for the formation of seed under irrigated treatments. These results were in agreement with the findings reported by Rana et al. (2019), Dash et al. (2013) and Ray et al. (2015) ${ }^{[12,2,15]}$. The yield attributes of mustard improved with the subsequent doses of $\mathrm{N}$ along with irrigation scheduling. Application of $120 \mathrm{~kg} \mathrm{~N} /$ ha resulted in highest number of siliqua per plant (190), seeds per siliqua (16.1) and test weight (3.9). Least 
response in this yield attributes were observed with application of $40 \mathrm{~kg}$ N/ha. During crop growth, supply of nutrients and availability of assimilates for pod set and seed filling are decisive factors affecting yield. For Indian mustard, the sink lies in the siliqua and seed and hence, under optimum supplies of $\mathrm{N}$ this greater translocation of photosynthates from leaf to siliqua resulting in robust siliqua and seeds (Hocking et al. 1997) ${ }^{[8]}$. Nitrogen stimulates plant growth by means of enlarged leaf canopy and a greater rate of leaf expansion, resulting in higher pods and higher seed number per pod possibly because of increased meristematic activity and development of more flowers and siliqua (Rathore et al. 2014) [14].

\section{Seed Yield}

The seed yield and biological of hybrid mustard crop was significantly influenced by irrigation and nitrogen management practices. The data on seed yield and biological yield substantiate this observation (Table 2). The maximum seed yield of $1606 \mathrm{~kg} / \mathrm{ha}$ and maximum biological yield of $5470 \mathrm{~kg} / \mathrm{ha}$ were recorded with IW/CPE=1.2. The least seed yield of $1371 \mathrm{~kg} / \mathrm{ha}$ and least biological yield of $5282 \mathrm{~kg} / \mathrm{ha}$ was noted in IW/CPE $=0.8$ irrigation schedule. Yield variation due to irrigation regimes was to the tune of 9.18 to $17.14 \%$. The correlation study between yield attributes and seed yield revealed a high $\mathrm{R}^{2}$ value ranging from 0.72 to 0.97
(Fig. 1), which indicate that increase in yield was largely attributed due to positive change in yield attributes. Moreover, adequate supply of moisture favourably improved nutrient uptake and translocation which ultimately increased the yield. The different levels of nitrogen doses applied in hybrid mustard crop had significant effect on seed yield with the variation of 26.98 to $83.09 \%$. Among the nitrogen levels 120 $\mathrm{kg} / \mathrm{ha}$ had recorded maximum seed yield of $1906 \mathrm{~kg} / \mathrm{ha}$ followed by $80 \mathrm{~kg} / \mathrm{ha}(1501 \mathrm{~kg} / \mathrm{ha})$. Similarly, the nitrogen levels of $120 \mathrm{~kg} / \mathrm{ha}$ had recorded maximum biological yield of $6908 \mathrm{~kg} / \mathrm{ha}$ followed by $80 \mathrm{~kg} / \mathrm{ha}$ (5053 kg/ha). As mentioned earlier the higher availability of nitrogen to the mustard plant root during the crop season had augmented plant growth and further enhanced the yield attribute. These led to higher seed yield, which is also validated by the positive correlation between the yield attributes and yield data (Fig. 1).

Interaction effect of irrigation and nitrogen levels on seed yield of hybrid mustard crop was found significant (Table 3). The maximum yield of hybrid mustard $2016 \mathrm{~kg} / \mathrm{ha}$ was achieved in IW/CPE=1.2 with $120 \mathrm{~kg} \mathrm{~N} /$ ha followed by the treatment IW/CPE=1 (1918 kg/ha) with the same dose of $\mathrm{N} / \mathrm{ha}$ and the least yield was noted with the irrigation treatment of IW/CPE=1.2 with $40 \mathrm{~kg} \mathrm{~N} / \mathrm{ha}$. It was found that the enhanced moisture supply have increased the nitrogen availability to the plant throughout the crop growth, which finally resulted in high seed yield.

Table 1: Effect of irrigation schedules and nitrogen management on plant height, dry matter accumulation, CGR and number of branches of hybrid mustard

\begin{tabular}{|c|c|c|c|c|}
\hline Treatment & Plant heigth (cm) & Dry matter accumulation $\left(\mathrm{g} / \mathrm{m}^{2}\right.$ & CGR (g/m²/day) & No of branches \\
\hline \multicolumn{5}{|c|}{ Irrigation schedule (IW/CPE) } \\
\hline I1-0.8 & 146 & 771.0 & 10.8 & 11.2 \\
\hline I2-1.0 & 148 & 706.2 & 9.2 & 9.7 \\
\hline I3-1.2 & 150 & 873.6 & 12.9 & 10.8 \\
\hline S. $\operatorname{Em}( \pm)$ & 2.44 & 23.40 & 0.25 & 0.24 \\
\hline $\mathrm{CD}(P=0.05)$ & 7.80 & 63.69 & 1.01 & 1.00 \\
\hline \multicolumn{5}{|c|}{ Nitrogen(Kg/ha) } \\
\hline $\mathrm{N} 1-40$ & 142 & 579.4 & 7.9 & 8.2 \\
\hline N2- 80 & 147 & 729.8 & 9.4 & 9.7 \\
\hline N3- 120 & 155 & 1041.7 & 15.6 & 13.7 \\
\hline S. Em $( \pm)$ & 2.63 & 21.82 & 0.23 & 0.16 \\
\hline $\mathrm{CD}(P=0.05)$ & 7.12 & 61.11 & 0.72 & 0.51 \\
\hline
\end{tabular}

Table 2: Effect of irrigation scheduling and nitrogen management on yield attributes and yield of hybrid mustard

\begin{tabular}{|c|c|c|c|c|c|}
\hline Treatment & No of siliqua/plant & Seeds/siliqua & Test weight (g) & Biological yield (kg/ha) & Seed yield (kg/ha) \\
\hline \multicolumn{6}{|c|}{ Irrigation(IW/CPE) } \\
\hline $\mathrm{I} 1-0.8$ & 125 & 13.0 & 3.4 & 5282 & 1371 \\
\hline I2-1.0 & 117 & 14.1 & 3.7 & 5395 & 1471 \\
\hline I3-1.2 & 140 & 15.0 & 3.6 & 5470 & 1606 \\
\hline S. Em $( \pm)$ & 2.54 & 0.10 & 0.004 & 57.2 & 44.8 \\
\hline $\mathrm{CD}(P=0.05)$ & 6.88 & 0.41 & 0.018 & 143.1 & 112.32 \\
\hline \multicolumn{6}{|c|}{ Nitrogen(Kg/ha) } \\
\hline $\mathrm{N} 1-40$ & 87 & 12.0 & 3.2 & 4470 & 1041 \\
\hline N2- 80 & 106 & 14.0 & 3.6 & 5053 & 1501 \\
\hline N3- 120 & 189 & 16.1 & 4.0 & 6625 & 1906 \\
\hline S. Em $( \pm)$ & 2.11 & NS & 0.015 & 54.1 & 42.3 \\
\hline $\mathrm{CD}(P=0.05)$ & 6.38 & NS & 0.046 & 140.3 & 108.11 \\
\hline
\end{tabular}

Table 3: Interaction effects of irrigation scheduling and nitrogen management on seed yield of hybrid mustard

\begin{tabular}{|c|c|c|c|c|}
\hline \multirow{2}{*}{ Nitrogen levels (kg /ha) } & \multicolumn{4}{|c|}{ Seed yield (kg/ha) at different irrigation levels } \\
\cline { 2 - 5 } & IW/CPE=0.8 & IW/CPE=1.0 & IW/CPE=1.2 & 1198 \\
\hline 40 & 1003 & 924 & 1603 & 1041 \\
\hline 80 & 1327 & 1572 & 2016 & 1901 \\
\hline 120 & 1783 & 1918 & 1606 & \\
\hline Mean & 1371 & 1471 & I X N & N X I \\
\hline
\end{tabular}




\begin{tabular}{|c|c|c|c|}
\hline S.Em $( \pm)$ & 44.8 & 42.3 & 53.12 \\
\hline CD $(P=0.05)$ & 112.32 & 108.11 & 135.11 \\
\hline
\end{tabular}
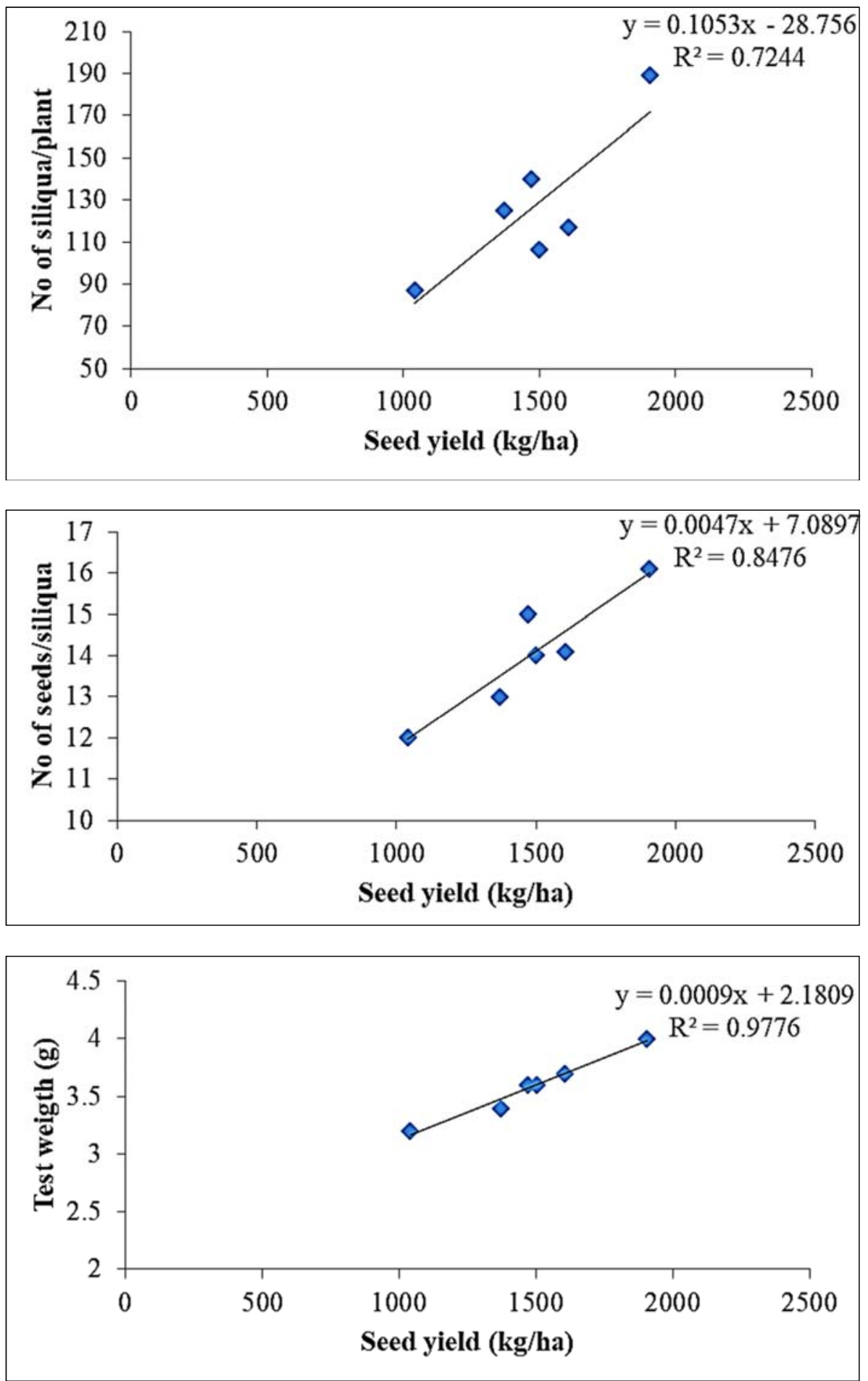

Fig 1: Correlation between yields attributes and seed yield

\section{Conclusion}

Indian mustard (Brassica juncea) is an important edible oilseed crop in Indian. It is mainly grown under limited water availability conditions in semi-arid areas. Proper irrigation scheduling and $\mathrm{N}$ management can enhance the growth and development of mustard crop and increase its productivity. Based on our findings it was concluded that irrigation scheduling done at IW/CPE=1.2 along with application of 120 $\mathrm{kg} \mathrm{N} /$ ha results in higher growth and yield in hybrid mustard.

\section{References}

1. Dadhich RK, Meena RS, Reager ML, Kansotia BC. Response of bio-regulators to yield and quality of Indian mustard (Brassica juncea L. Czernj. and Cosson) under different irrigation environments. Journal of Applied and Natural Sciences 2015; 7(1):52-57.

2. Dash AK, Nayak BR, Panigrahy N, Mohapatra S and Samant PK. Performance of groundnut (Arachis 
hypogea) under different levels of sulphur and irrigation. Indian Journal of Agronomy. 2013; 58(4):578-82.

3. Dhawan BD. Technological change in irrigated agriculture: a study of water saving methods. Commonwealth Publishers, New Delhi, 2002.

4. DOAC. Agricultural statistics at a glance. Directorate of Economics and Statistics, Department of Agriculture and Cooperation. Ministry of Agriculture, Government of India, 2018.

5. Evans GC. Quantitative Analysis of Growth. Oxford: Blackwell Scientific Publications, 1972.

6. Ghosh PK, Wanjari RH, Mandal KG, Hati KM, Bandyopadhyay KK. Recent trends in interrelationship of nutrients with various agronomic practices of field crops. Indian Journal of Sustainable Agriculture 2002; 21:47-77.

7. Gomez KA, Gomez AA. Statistical procedures for agricultural research. USA: John Wiley, Sons, 1984.

8. Hocking PJ, Kirkegard JK, Angus AHG, Koetz EA. Comparison of canola, Indian mustard and linola in two contrasting environments. III. Effects of nitrogen fertilizer on nitrogen uptake by plants and on soil nitrogen extraction. Field Crops Research 1997; 79:153172.

9. Namara RE, Nagar RK, Upadhyay B. Economics, adoption determinants, and impacts of micro-irrigation technologies: empirical results from India. Irrigation Science. 2007; 25:283-297.

10. Piri I, Sharma SN. Physiological analysis of growth and yield of Indian mustard as affected by irrigation and sulphur. Indian Journal of Plant Physiology. 2006; 11(3):253.

11. Piri I, Nik MM, Tavassoli A, Rastegaripour F, Babaeian M. Effect of irrigation frequency and application levels of sulphur fertilizer on water use efficiency and yield of Indian mustard (Brassica juncea). African Journal of Biotechnology. 2011; 10(55):11459-11467.

12. Rana K, Parihar M, Singh JP, Singh RK. Effect of sulfur fertilization, varieties and irrigation scheduling on growth, yield, and heat utilization efficiency of indian mustard (Brassica Juncea L.). Communications in Soil Science and Plant Analysis, 2019, 1532-2416;

13. Rathore SS, Shekhawat K, Kandpal BK, Premi OP. Improvement of physiological and productivity traits of Indian mustard (Brassica juncea L.) through microirrigation and fertigation under hot semi-arid eco-region. Indian Journal of Agricultural Sciences 2017; 87(9):1257-1262.

14. Rathore SS, Shekhawat K, Kandpal BK, Premi OP. Micro-irrigation and fertigation improves gas exchange, productivity traits and economics of Indian mustard (Brassica juncea L. Czernj and Cosson) under semi-arid conditions. Australian Journal of Crop Science. 2014; 8(4):582-595.

15. Ray K, Sengupta K, Pal AK, Banerjee H. Effects of sulphur fertilization on yield, $\mathrm{S}$ uptake and quality of Indian mustard under varied irrigation regimes. Plant, Soil and Environment. 2015; 61(1):6-10.

16. Yadav RP, Tripathi ML, Trivedi SK. Yield and quality of Indian mustard (Brassica juncea) as influenced by irrigation and nutrient levels. Indian Journal of Agronomy. 2010; 55(1):56-59. 